\title{
A study on the effect of Kutaki (Picrorrhiza kurroa) on Hypertension
}

\begin{tabular}{c} 
Vinod Dattarao Patange* \\
Lecturer, Department of Dravyaguna, \\
S.C. Mutha Aryangla Vaidyak Mahavidyalaya,Satara. \\
\hline
\end{tabular}

Abstract

Hypertension is abnormal increase in the blood pressure. It leads to many fatal conditions like heart failure, cerebral haemorrhage, renal disease, dissecting aortic aneurysms etc. It is characterized by the elevated blood pressure and includes symptoms like Shirah-shul (headache), Bhrama (giddiness), etc. According to Ayurveda, hypertension is caused by the vitiation of pitta, rakta, meda and obstructing the channels of the body. So to cure the disease a drug having the properties of reducing pitta, meda, rakta and cleaning the channels of the body is preferred. So a herbal drug Kutaki (Picrorrhiza kurroa) having the similar properties has been taken for the study to understand its effect on Hypertension. An open end clinical trial was conducted on 30 patients of primary hypertension and drug was administered internally in a dose of 250 mg twice daily along with jaggery for 15 days. The results showed that there is mild to moderate relief in the patients with the drug and no untoward side-effects were seen in any patients.

Key words: Kutaki, Picrorrhiza kurroa, Hypertension.

\section{Introduction:-}

Now a day's sedentary life style is one of the causes of hypertension. It is one of the commonest causes for other major disorders like ischemic heart disease and other pulmonary and renal conditions.

Hypertension is generally assymptomatic and is found on routine general examination of the blood pressure. Some patients express it with

\footnotetext{
*Address for correspondence:

Vinod Dattarao Patange.

Lecturer, Department of Dravyaguana,

S.C. Mutha Aryangla Vaidyak

Mahavidyalaya,Satara.

E-mail: vinodpatange@ rediffmail.com

Ph.No: +91-9028067171
}

the symptoms of headache, giddiness, sleeplessness etc. According to WHO if systolic B.P is more than 160 and diastolic is less than 95 this comes under High Blood Pressure category. (3)

The symptoms generally observed in the patients of hypertension are similar to various conditions mentioned in the Ayurvedic texts like brama, anidrata etc. the causative factors to the above symptoms involve the vitiation of pitta, rakta, meda and kapha and causing the abnormal functioning of vyana vayu. (4)

This occurs because of the factors causing vitiation of Pitta like spicy foods, Cigar smoking, Tobacco chewing, alcoholism, awakening late in the night (Atijagaran), excessive consumption of 
pungent and salty diet, and some psychological factors like fear, anger etc play a major role in the vitiation of the doshas.

Because of the above causes there will be Pittaprakopa which vitiates Rakta and due to today's sedentary lifestyle there will be Medodhatwagnimandya which causes Dhamanipratichaya which obstructs Vyana-vayu causes Raktabhara Vrudhhi. So, we can call this disease as Pitta, Meda-Raktavrutta Vyana vata.

The treatment of it include a drug which can pacify the doshas pitta and kapha and reduce meda and regulate the functions of the vyana vata. Hence for the present study the herbal drug Kutaki Latin name- Picrorrhiza kurroa was taken for the study.

\section{Selection of the drug: (1-2)}

Porperties of the drug: RasaTikta, Veerya- Katu, Veerya- Sheeta, Guna - Ruksha, Laghu, KarmaDeepana, Bhedana, Hridya, Doshaghnata-Kapha-Pittghna, Rogaghnata-Prameha, Swasa, Kasa, Raktavikara, Kusta and Krumivikara.

By the above said properties Kutki was selected for the treatment of Hypertension. It clears the path of Srotasas which is obstructed by Dusta Kapha and Dusta pitta.

\section{Preparation and dosage with duration of treatment-}

The drug is powdered finely and is administered in a dose of $250 \mathrm{mg}$ for 15 days. The powdered drug is bitter in taste hence to make it palatable it is mixed with equal quantity of jaggery

\section{Aims and objectives of the study:}

The aim of the study is to access the efficacy of Katuki powder in the cases of Hypertension.

\section{Material and methods:-}

An open end trial was conducted in 30 patients) in the age group of 20 to $60 \mathrm{yr}$, whose informed consent was obtained before commencement of the study. The study was conducted in Dr. M.N.Agashe Charitable Trusts Hospital, Shukravar Petha, Satara. Signs and symptoms as well as Blood Pressure examined.

\section{Dosage:}

250 mg Katuki churna with 250 gm of jaggery twice in a day.

\section{Duration:}

15 days.

\section{Inclusion criteria:}

- Patients between the age group of 20-60 years of age.

- Patients diagnosed as hypertensive.

- Patients not having any fatal complications.

\section{Exclusion criteria:}

- Patients above 60 years of age.

- Patients having complications like previous history of stroke, cardiac failure etc.

- Pregnant, lactating and cachexic patients were excluded from the study.

\section{Assessment:}

Patients are asked to come for checkups once in a week for two visits. The most common symptoms of hypertension, headache (shirashula), giddiness (bhrama), hriddravya (heaviness the chest), oedema (shotha), dyspnoea (shwasaktata) are recorded for their presence or absence and the assessment is made by the following based on the relief of the symptoms 
Blood pressure was checked by the sphygmomanometer and the categorized as normal $(120 / 80 \mathrm{~mm}$ of $\mathrm{Hg})$, mild $(<130 / 90 \mathrm{~mm}$ of $\mathrm{Hg})$, moderate $(<140 / 100 \mathrm{~mm}$ of $\mathrm{Hg})$ and severe $(>140 / 100 \mathrm{~m}$ of $\mathrm{Hg}$ ).

\section{Results (Table 1):-}

Out of 15 patients, 12 patients completed the trial. It is observed that of the 12 patients 9 has Shirahshula, 05 has Bhrama, 05 had Hridadrava, 06 has Anidra, 03 patients has Smrutibhramsha, 05 has Swasa kastata, 08 has Shotha, 04 has Urahshula, 06 patients having Atisweadapravrutti, 07 patients are Habitual to tobacco or alcohols, 10 patients are having Krodhaprachurata, All the patients were consuming mixed diet and all the patients were Married. Of the 15 patients 05 were mild Hypertensive patients, 05 were moderately Hypertensive and 02 were severely Hypertensive.

After giving the drug Kutaki in a dose of $250 \mathrm{mg}$ two times a day for 15 days, it is observed that mild Hypertensive patients were 08, Moderate- 03 and 1 patient has got complete relief.

It is also observed that this drug decreases the symptoms of Shirahshula (50\%), Bhrama (60\%), Swasakastata (75\%), Shotha (50\%), Urahshula (50\%).

Table 1: Showing the results obtained

\begin{tabular}{|l|l|l|}
\hline \multirow{2}{*}{ Symptoms } & \multicolumn{2}{|c|}{ No of patients (percentage) } \\
\cline { 2 - 3 } & Before treatment & After treatment \\
\hline Shirahshula & $09(74.97 \%)$ & $06(66.66 \%)$ \\
\hline Bhrama & $05(41.66 \%)$ & $03(60 \%)$ \\
\hline Hriddravata & $05(41.66 \%)$ & $03(60 \%)$ \\
\hline Anidra & $06(50 \%)$ & $00(0 \%)$ \\
\hline Swasakastata & $05(41.66 \%)$ & $04(75 \%)$ \\
\hline Shotha & $08(66.66 \%)$ & $04(50 \%)$ \\
\hline Urahshula & $04(33.33 \%)$ & $02(50 \%)$ \\
\hline Mild Hypertension & $05(41.66 \%)$ & $08(66.66 \%)$ \\
\hline Moderate Hypertension & $05(41.66 \%)$ & $03(25 \%)$ \\
\hline Severe Hypertension & $02(16.66 \%)$ & Nil \\
\hline
\end{tabular}

\section{Discussion and conclusion: -}

Hypertension is the disease which, though has not been mentioned directly in Ayurvedic texts it can be considered as Avrutta vata, specifically as PittaMeda-Raktavrutta -Vyana.

Kutaki is the drug which has Kapha-Pittahara properties as well as Deepan, Bhedana and Hrudya karma along with Laghu and Ruksha guna. Laghu guna is easily digestible and ruksha guna which absorbs the Kleda of
Medadusti, Pittadusti and relives obstruction. So the drug was taken for the study and the study was conducted to know its effects.

From the above study it was observed that a few symptoms of the hypertension have reduced but the overall effect showed moderate effect of the Katuki on Hypertension.

From this study it can be concluded that Kutaki can be used in the mild to moderate hypertension. As it was 


\section{International Journal of Ayurvedic Medicine, 2010, 2(1), 48-51}

a pilot study, the sample size is very less the experiment has to be conducted in a large sample for the statistically viability.

\section{Acknowledgement: -}

I am thankful to Dr. Prakash Chavan, Principal, S.C.Mutha Aryangla Vaidyak Mahavidyalaya for giving permission to conduct trials in Hospital OPD and also thankful to Dr.Rajendra Gaikwad, OPD Incharge.

\section{References:}

1. Bapalal G. Vaidya, Nighantu adarsh uttarardha, Second edition, Varanasi; Chaukhambha Bharati academy; 1999, p.172

2. Sharma PV, Dravyaguna Vijnana, vol-2, reprint, Varanasi, Chaukhambha Bharati academy; 1999; p.441

3. Kumar P, Clarke M, Clinical Medicine, $3^{\text {rd }}$ edition, London, ELBS publishers; 1994; p.618625.

4. Lalchand vaidya, Sushruta samhita of Sushruta, $5^{\text {th }}$ edition, Delhi, Motilal Banarsidass, 1997; p.403-417. 